ORIGINAL ARTICLE

\title{
THE INNOVATIVE ROLES OF COMMUNITY ENGAGEMENT AS A MODERATOR IN CONSUMER PERSPECTIVE MODEL FOR MALAYSIA-ORIGIN FASHION BRANDS' BUSINESS SUSTAINABILITY
}

\author{
Siti Fatimah Hashim ${ }^{1 *}$, Rosita Mohd. Tajuddin ${ }^{1}$ and Amer Shakir Zainol ${ }^{1}$ \\ ${ }^{1}$ Faculty of Art \& Design, University Technology MARA, Shah Alam, Malaysia
}

\begin{abstract}
Community Engagement (CE) is investigated in this study as a moderator on whether it can innovatively strengthen the Consumer Perspective Model (CPM) or the opposite, in order to build Strong Brand Equity (SBE) for Malaysia-Origin Fashion Brands' (MOFBs) business sustainability. CE has been stated to have significant impacts especially through electronic Wordof-Mouth (eWOM) on sustainable advantage. CPM is a strategic brand management model adapted from Consumer-based Brand Equity (CBBE) (Keller, 1993) with Independent Variables (IVs) of Brand Awareness (BA), Brand Image (BI) and Purchase Intention (PI) to predict Dependent Variable (DV) of SBE building for MOFBs like Padini, Vinci, Polo Haus, Variante and others that have low equity to win over international rivals (IRs) such as H\&M, ZARA, Mango, Uniqlo and others, due to consumers switching their brand preferences. CE provides a good eWOM platform for consumer-brand relationship, thus, would turn commercial content moderation to financial outgrowth in its moderating effects together with Brand Loyalty $(\mathrm{BL})$ as a mediating variable. The study employed a non-probability convenient sampling technique with the success response rate of $29.7 \%$ where 798 datasets were run through data screening procedures for further statistical analysis in SEM-PLS. A quantitative research method by using SPSS version 25 and SmartPLS version 3.2 .8 on 6 constructs and 17 latent variables was employed too. The findings showed that Brand Loyalty has full mediating effects. CE was found to weaken the relationships between IVs and DV, thus, insignificantly affecting the innovative roles as a moderator variable. Overall, MOFBs are perceived of having low equity in the marketplace. Therefore, different consumers' perspectives to successfully build SBE are needed. Particularly, more comprehensive and innovative roles of CE in eWOM interactivities can contribute to business sustainability.
\end{abstract}

\author{
ARTICLE HISTORY \\ Received:14-4-2020 \\ Accepted:3-6-2020
}

\section{KEYWORDS}

Consumer Perspective

Model

Brand Awareness

Brand Image

Purchase Intention

Brand Loyalty

Community Engagement

Strong Brand Equity

Business Sustainability

Malaysia-Origin Fashion-

Brands

\section{INTRODUCTION}

The sustainability of MOFBs in business is the current focal point of the study. Past studies showed that CE has significant impacts for sustainable advantage, especially through interactivities of consumers in eWOM (Carvalho \& Fernandes, 2018; Srivastava \& Sivaramakrishnan, 2020). Therefore, CE as a moderator variable is investigated in this study whether it can innovatively strengthen the causal relationships in CPM which is adapted from the CBBE model (Keller, 1993). CPM consists of exogenous variables of BA, BI, and PI to predict SBE building for the sustainable advantage of MOFBs like Padini, Vinci, Polo Haus, Variante, and others that have low equity in the Malaysian Fast Fashion Industry (MFFI). Low equity brands have been identified as facing difficulties in financial outgrowth and struggling to sustain (Aaker, 1996; Aaker \& Biel, 2013; Keller, 1993, 2001). In addition, BL is investigated on the mediating effects in the causal relationships. CE is believed to provide a good platform for online social interactivities namely, eWOM, for business advantages (Tajuddin, Hashim \& Zainol, 2018). Businesses would have turned commercial content moderation to financial outgrowth by managing the online communities effectively (Seering, Wang, Yoon \& Kaufman, 2019). Besides, Carvalho and Fernandes (2018) identified CE as an effective moderator involving online determinants as such satisfaction, trust, and commitment in eWOM. Due to technological advancement, eWOM can give feedbacks related to post-purchase experiences to influence the purchase decision-making process (Nguyen \& Nguyen, 2019). According to Srivastava and Sivaramakrishnan (2020), brands should not ignore the advantages of CE's innovative roles in the consumer-brand engagement of eWOM to achieve satisfaction and loyalty. Thus, conquering market share is attainable as brand equity is strengthened.

\section{Problem statement}

MFFI is expected to worth $\$ 1.039$ million in 2020 with a growing Compound Annual Growth Rate (CAGR) of $8.4 \%$ in 2024 (Statistica, 2020). In reality, MOFBs face difficulties being the market leader as they struggle in surviving and sustaining their business. Particularly, they also struggle to fight with IRs such as H\&M, ZARA, Mango, Uniqlo, and others (Nielsen, 2017). A report from The EdgeProp highlighted MOFBs faced intense competition where a big player like PADINI Holdings that holds several brands under its belts has experienced decreasing in sales by $42.5 \%$ due to 
brand-switching behaviour (TheEdge, 2018). The situation is in favour of IRs as they hold outstanding global image and recognition which managed to attract young generations in their preferences (TheEdge, 2018; Valaei \& Nikhashemi, 2017; Mohamed, Mohamad, Borhan, Osman \& Kamaralzaman, 2019). Hence, the factor of country-of-origin (CoO) image and recognition are the strong determinants in influencing their purchase decisions (Valaei \& Nikhashemi, 2017; Mohamed et. al., 2019).

IRs are current the market leader as they have high equity perceived, thus, conquering the market share is attainable. On the contrary, MOFBs being resilient is questionable. Hence, $\mathrm{CE}$ as a moderator variable is investigated whether it can innovatively strengthen the causal relationships in CPM. Past studies found that low equity brands would experience financial instability due to consumer perspective behaviour (Aaker, 1991, 1996; Keller, 1993, 2001). Past literature had foreseen CPM as a strategic brand management tool to assist in predicting SBE building for sustainable advantage (Keller, 1993, 2001; Su \& Chang, 2018; Yeap, Thurasamy \& Yapp, 2018; Carvalho \& Fernandes, 2018; Seering et. al., 2019; Srivastava \& Sivaramakrishnan, 2020).

\section{Research objectives}

The main objective of the study is to investigate the innovative roles of CE as a moderator in CPM whether it can strengthen or weaken the causal relationships together with three (3) specific objectives which are formulated as below:

1. To investigate the mediator effects of BL in the relationships between IVs and DV

a. To investigate the moderator roles of CE whether it can innovatively strengthen or weaken the relationships between IVs and DV

2. To investigate the significant direct impacts of CPM in the relationships between IVs and DV

\section{LITERATURE REVIEW}

\section{Theoretical framework aligned in underpinning theories}

The study adapted the CBBE of Keller (1993) that consists of consumers' differential responses towards brand knowledge that are cognitively instilled in minds through marketing-mix activities over time. Themixedx marketing activities comprise of consumers' perceptions on ten (10) marketing elements as suggested by Chattopadhyay, Shivani, and Krishnan (2010) which are price, store image, distribution intensity, advertising frequency, celebrity endorsement, price promotion, non-price promotions, event sponsorship, country-of-origin, and word-of-mouth (WOM).

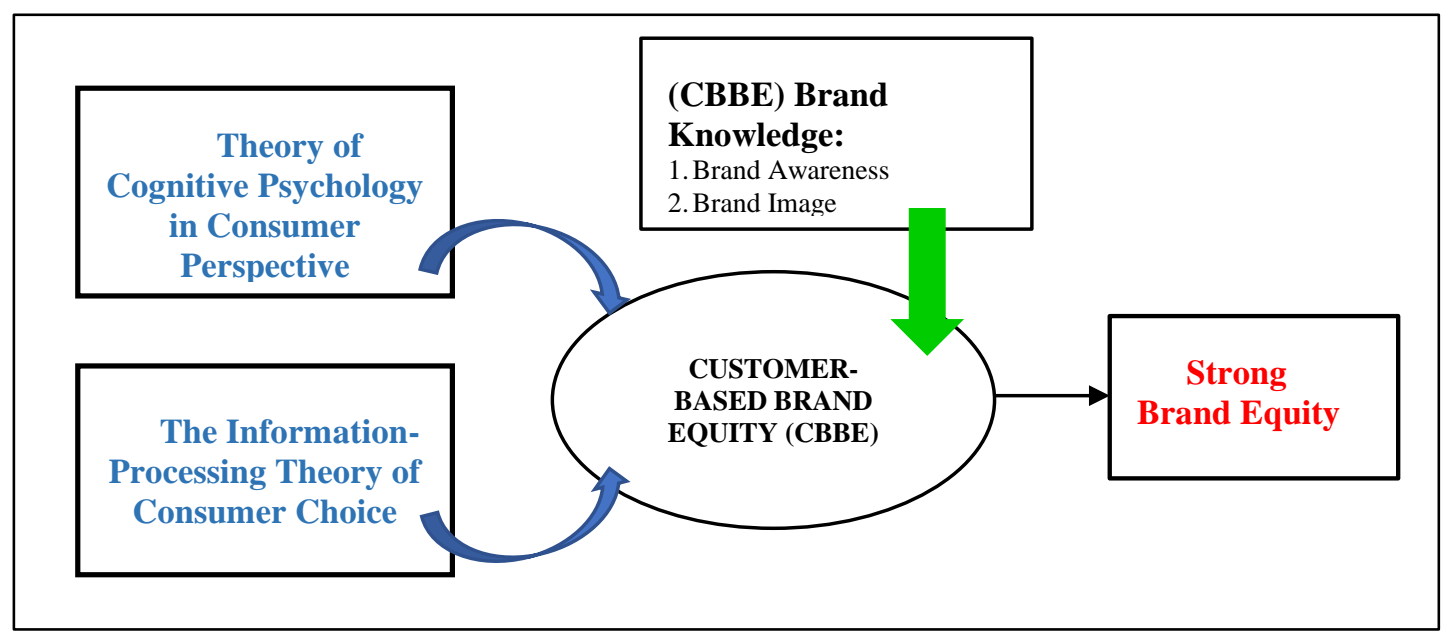

Figure 1. Theoretical framework

Based on CBBE, a theoretical framework is general directions for the relationships identified which are crucial to the issue being investigated. The underpinning theories adapted from the Theory of Cognitive Psychology in Consumer Perspective (Fischer, 1980) and Information-Processing Theory of Consumer Choice (Bettman, 1970, 1979) are integrated with CBBE which incorporates Brand Knowledge leveraging in BA and BI (Keller, 1993). Figure 1 illustrates the theoretical framework of the study. 


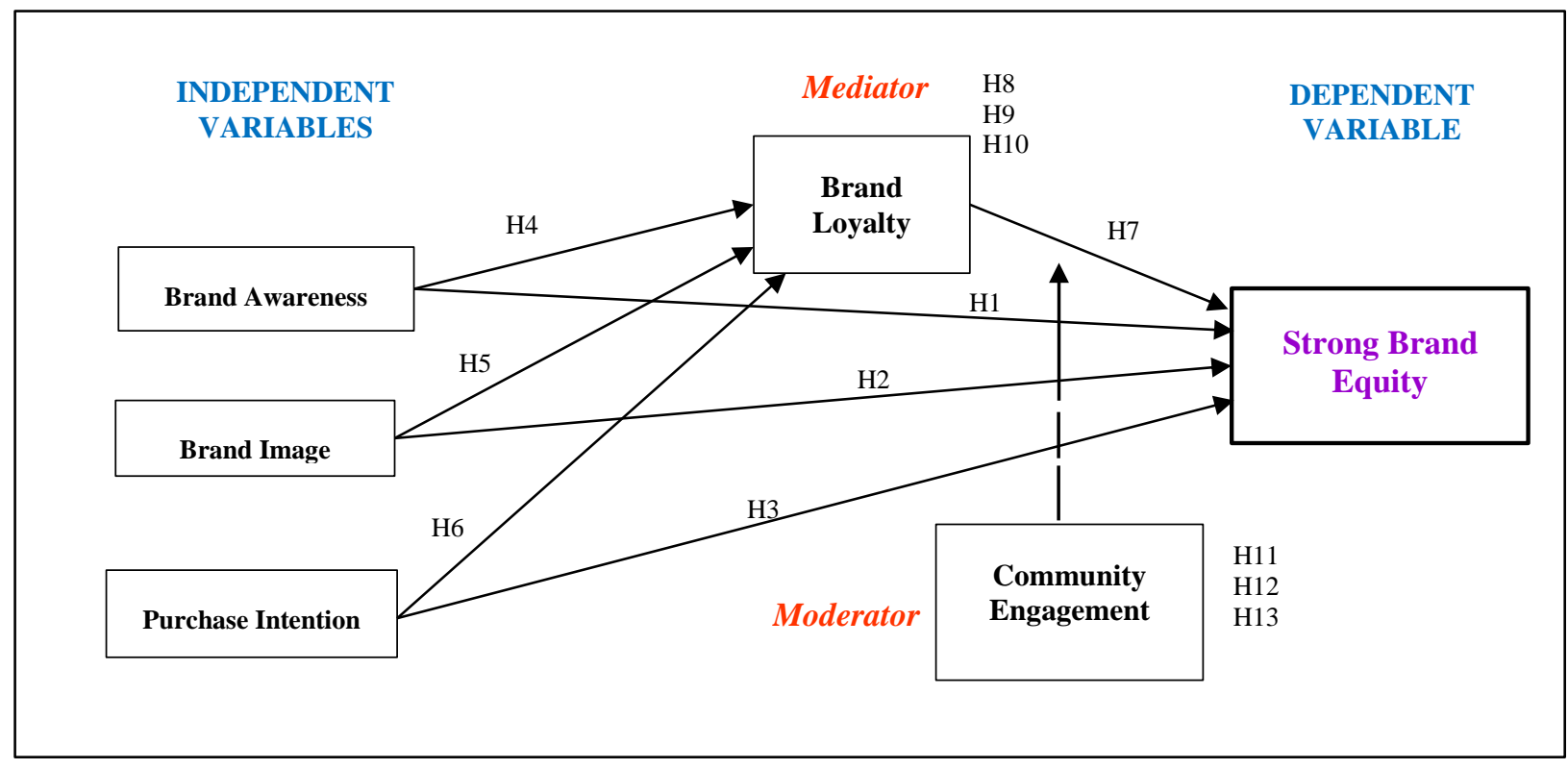

Figure 2. Conceptual framework of consumer perspective model (CPM)

\section{Conceptual framework and hypotheses development}

$\mathrm{CPM}$ is established in BA, BI and PI construct to predict SBE building in the causal relationships as a specific direction to the study. Moreover, BL and $\mathrm{CE}$ are examined as the mediator and moderator variables in the causal relationships. Figure 2 illustrates the conceptual framework and hypotheses development that was elaborated further.

\section{Direct impacts of CPM on SBE building}

CPM is elaborated in brand knowledge which is cognitively instilled in consumers' minds that motivates consumers' various responses towards mix-marketing activities over time. It comprises of BA, BI, and PI determinants that have been identified for SBE building (Aaker, 1996; Aaker \& Biel, 2013; Acar \& Erkan, 2018; Keller, 1993, 2001, Keller \& Brexendorf, 2016). The familiarization of a brand indicates high BA due to consumers' ability to recall and recognize the brand against other rivals, as it has distinguished product cues to influence purchase decision-making, contributing to SBE building (Keller \& Brexendorf, 2016; Foroudi, 2019). In addition, image differentiation has positive impacts on consumer behaviour developed in brand associations of product and non-product attributes congruently. It also enhances trust and satisfaction levels to further strengthen brand equity (Keller, 2016; Foroudi, 2019). Furthermore, PI is also identified as a contributor to SBE establishment via post-purchase evaluation, leading to positive buying patterns in purchase repetitions and recommendations, which lead to SBE building (Foroudi et. al., 2018). Thus, the study proposed the following hypotheses as below;

\section{H1: BA has a significant direct impact on SBE Building}

H2: BI has a significant direct impact on SBE Building

H3: PI has a significant direct impact on SBE Building

\section{CPM towards brand loyalty development}

CPM is believed to develop BL, leveraging from BA, BI, and PI determinants where a pool of loyal consumers is advantageous for business growth (Keller, 1993; Aaker, 1996; Foroudi et. al., 2018). BA is seen as a prerequisite to BL development which benefited from recognition and recalls characteristics in the communicating process to develop familiarity and popularity of a brand (Aaker, 1996; Foroudi et. al., 2018). Meanwhile, BI is reflected in brand associations held in consumer's mind to create meanings attributed in different circumstances and experiences which develop into BL establishment (Keller, 1993; Aaker, 1996; Foroudi et. al., 2018; Ahn, 2019). Furthermore, BL is established once consumers show a positive attitude and behaviour in their purchase intention based on satisfaction and trust (Keller, 1993; Aaker, 1996; Aminu \& Ahmad, 2018; Ahn, 2019). Thus, the following hypotheses are proposed; 


\section{Brand loyalty predicts the SBE building}

Past studies agreed that loyalty can predict SBE building established in consumers' satisfaction and trust in the consumer-brand relationship (Aaker, 1991, 1996; Aaker \& Beil, 2013; Keller, 1993, 2016; Foroudi et. al., 2018). Recruiting new consumers is expensive, hence, retaining loyal consumers is the best alternative. Intangible brand strength can be seen in loyalty magnitudes through the willingness to pay a price premium, insensitive towards price-change, and positive attitude towards repurchase and advocacy commitments (Braun, 2018; Gómez, Martín-Consuegra, Díaz \& Molina, 2018). Thus, another hypothesis is proposed;

\section{H7: BL has significant effects on SBE building}

\section{Brand loyalty as a mediator in the causal relationships}

Past studies recommended BL as a mediator variable leveraging brand knowledge with determinants of BA, BI, and PI for SBE building (Keller, 1993; Aaker, 1996; Keller, 2016; Keller \& Brexendorf, 2016; Acar \& Erkan, 2018). Loyalty directly affects consumers' brand of choice which comes from familiarization in recalls and recognitions, indicating SBE existence (Keller, 1993; Aaker, 1996). Besides, the premise of BI is discovered in functional and symbolic attributes, mediated by BL for SBE building. Past studies indicated a significant relationship between BI and SBE in differentiation which needed supports from the loyalty of retained consumers who congruently perceive brand-concept and value-added attributes (Nguyen, Wu \& Chen, 2017; Zhu, Teng, Foti \& Yuan, 2019). Moreover, consumers' attitudinal and behavioural intentions are commitments triggered by high loyalty to enhance SBE building. This situation indicates that the motivation of PI highly contributes to SBE establishment through loyal consumer-brand relationships (Khan, Rahmani, Hoe \& Chen, 2015; Rather \& Sharma, 2017). Hence, the following hypotheses are proposed;

\section{H8: BL has a mediator effect on the relationship between BA and SBE building \\ H9: $B L$ has a mediator effect on the relationship between BI and SBE building \\ H10: BL has a mediator effect on the relationship between PI and SBE building}

\section{CE as a moderator variable in the causal relationships}

CE provides a platform for a closed-knit bonding through eWOM interactivities for SBE building which is constructed in BA, BI, and PI dimensions. Past studies highlighted that CE interactivities were identified as a strategic driver to strengthen causal relationships (Carvalho \& Fernandes, 2018; Ahn, 2019; Srivastava \& Sivaramakrishnan, 2020). Thus, the utilization of consumer-brand and consumer-consumer relationships has become CE's major innovative role to strategically establish sustainable advantage for SBE building (Chan, Boksem \& Smidts, 2018). The optimization of CE interactivities is to create high BA in familiarization criteria (Zhang, Shabbir, Pitsaphol \& Hassan, 2015; Islam \& Rahman, 2016). On the contrary, brand associations develop positive attitudes towards a product and non-product dimensions in functional, performance-related, and imagery-related retrieved in the image perceived (Keller, 1993, 2001). Through the intrinsic and extrinsic properties, CE contributes to brand performance in quality and value, thus, supporting SBE building (Camilleri \& Rather, 2019). Therefore, valuable insights in consumers' perception can critically give feedbacks through intentional commitments to further strengthen the causal relationships in the purchase decision-making process (Keller, 1993, 2016; Aaker, 1996; Chan et. al., 2018). Therefore, the following hypotheses are proposed;

H11: CE moderates the relationship between BA and SBE building

H12: CE moderates the relationship between BI and SBE building

H13: CE moderates the relationship between PI and SBE building

\section{METHODOLOGY}

\section{Quantitative research method}

The quantitative research method was the most appropriate for this study as it focused on consumers' perceptions by adopting an integrated research model to guide specifically in questionnaires design, data collection procedures, and selection of statistical analysis (Corner, 2002). For questionnaire design, the study was aligned in three (3) levels starting from the adaptation of literature reviews, reviewing questionnaire draft in pre-testing, and conducting a pilot test (Chen $\&$ Paulraj, 2004). The questions were formed in closed-ended structured using multiple-choice questions which are suitable for a self-administered survey. The questionnaire was divided into six (6) different parts. Part A has fourteen (14) questions focusing on the consumer demography profiles. Meanwhile, Part B until Part F used a 7-point Likert scale categorized under interval level in measuring attitudinal scales for character and personality traits of the respondents. Those parts have ninety-nine (99) items in total with the range of (1) for 'Strongly Disagree' to (7) for 'Strongly Agree' (Joshi, Kale, Chandel \& Pal, 2015; Aini, Zuliana \& Santoso, 2018).

\section{Pre-testing}

Pre-testing was conducted to improve the readability, ambiguity, and validity of the questionnaire before proceeding to the actual data collection. Two (2) pre-testing sessions were conducted (Dillman, 2000; Howard, 2018). The first session consisted of thirty (30) participants from the sample population. They had to give comments and recommendations 
on the questionnaire (Perneger, Courvoisier, Hudelson \& Gayet-Ageron, 2015). On the contrary, the second session involved two (2) experts in the field of study to assess and evaluate the questionnaires to avoid any discrepancy in reaching content and face validity goals (Perneger et. al., 2015).

\section{Pilot study}

A small-scale study with the aim to assess the credibility of research instruments and feasibility to run an actual-large scale survey was conducted before the actual data collection (Nardi, 2018). Two (2) groups of twenty-five (25) individuals each from the sample population were involved in this pilot test (Hertzog, 2008). The questionnaires were distributed by using Google Form through social network platforms such as emails, Facebook, Messenger, and WhatsApp. The participants gave their constructive comments and feedbacks in which the study utilized to increase the rigor and trustworthiness of the results. In addition, the data collected were analyzed and tabulated by using Statistical Package for Social Science (SPSS) Software version 25 (Wagner III, 2019) in reliability testing for internal consistency between scales using Cronbach's Alpha coefficient scores (Taber, 2018).

\section{Quantitative research technique for data collection}

The sample population represented the entire population through the generalizability of MOFBs' consumers who stayed in Klang Valley areas. The power analysis was utilized in detecting the true effect by employing G*Power software version 3.1.9.2 to determine the sample size (Faul, Erdfelder, Lang \& Buchner, 2007; Tehseen, Sajilan, Gadar \& Ramayah, 2017; Ramayah, Cheah, Chuah, Ting \& Memon, 2018). Cohen's (1988) $f^{2}$ of 0.2, 0.5, and 0.8 for small, medium, and large effect sizes respectively were followed in this research. With the involvement of three (3) predictors, the study determined that a minimum sample size of sixty-eight (68) was needed to create a power of 0.95 with medium effect size $f^{2}=0.2$ under a two-tailed test. A non-probability convenient sampling technique was utilized for data collection where both non-conventional and conventional approaches were applied in online web-based and paper-based survey tools respectively (Mutepfa \& Tapera, 2019). Based on a study by Candrlic, Katić, and Dlab (2014) which was conducted on 1231 observed courses found that the median values of the results achieved during online and paper-based tests showed no significant differences.

Thus, the study employed the non-conventional approach of the online web-based questionnaire using Google Form linked to Facebooks, WhatsApp, Messenger, and emails. 2050 sets of questionnaires were distributed with a $31.5 \%$ success response rate in return (Mutepfa \& Tapera, 2019). Meanwhile, the conventional approach used a paper-based survey tool to distribute 800 sets of questionnaires with a $28.9 \%$ success response rate. This is due to the questionnaire being distributed in high-density areas which provide feasibility and practicality for easy accessibility, proximity, availability of respondents to participate. These high-density areas include shopping malls, higher institutions, and other crowded places (Speak, Escobedo, Russo \& Zerbe, 2018; Mutepfa \& Tapera, 2019). On average, 29.7\% of response rate successfully returned eight hundred forty-six (846) sets of questionnaires in both survey tools. Hence, a study by Candrlic et al., (2014) proved that only a slight difference occurred in both applications, indicating that the approaches were reliable to be employed for data collection in this study. However, after data screening procedures, only seven hundred ninetyeight (798) datasets were utilized for further statistical analysis.

\section{FINDINGS AND DISCUSSION}

\section{Respondents characteristics}

The gender characteristics showed $35 \%$ of respondents are male and $65 \%$ are female. $65.8 \%$ of the total respondents aged between 18 and 24 years old with monthly income status in the range of less than RM2000 to RM5000 monthly with $35.1 \%$ of them working full time. Malay respondents contribute to $80.6 \%$ of the total respondents where $71 \%$ are single young adults who stay in Klang Valley areas, with the highest residing in Wilayah Persekutuan Kuala Lumpur. The results show that respondents are actively buying goods online and offline. However, only $45.1 \%$ are members of MOFBs with $92.7 \%$ of them spending in the range of less than RM100 to RM300 in a single receipt, with the frequency of buying from one (1) to three (3) times in six months. They spend mostly on clothes and shawl/headscarf.

\section{Assessment of normality}

The results showed that the $p$-value $\leq 0.001$, indicating all variables are normally distributed. On the contrary, $z$-values for skewness and kurtosis showed that Price Premium has approximate normality in skewness at -1.488 , whereas, the rest of the constructs are non-normally skewed ranging from -6.348 to -2.465 indicating $z$-skewness are deviated from normality and not symmetrical in the data distribution. On the contrary, the values of $z$-kurtosis are normally distributed in the range of -1.912 to 1.228 . Overall, the results exhibited that the datasets are approximately non-normally distributed.

\section{Descriptive data analysis}

Descriptive data analysis measures the central tendency and dispersion, showing the central tendency at the range between 4.80 and 5.19. Standard Deviation's highest value is $(\sigma)=1.31622$ (BEPP), indicating the data points spread wider compared to other variables. In addition, Variance measures the average of the squared distances from the Mean to estimate the population of the study in the range between 0.986 (BIA) and 1.732 (BEPP). 


\section{Assessment of measurement model of low-order and high-order constructs}

A Reflective Measurement Model of Reflective-Formative Type II HOC 'Mode A' was analyzed to assess the Convergent and Discriminant Validity on variables and the corresponding items of Low-order construct (LOC). Figure 3 exhibits the model generated in 6 parameters of BA, BI, PI, BL, CE and to determine Convergent Validity in Factor Loading coefficients, Composite Reliability (CR), and Cronbach's alpha coefficient $(\alpha)$. Based on the results for the reflective LOC measurement model, all factor loading coefficients exceed the threshold value of 0.70 which indicates high reliability (Tehseen et. al., 2017; Hair, Risher, Sarstedt \& Ringle, 2019).

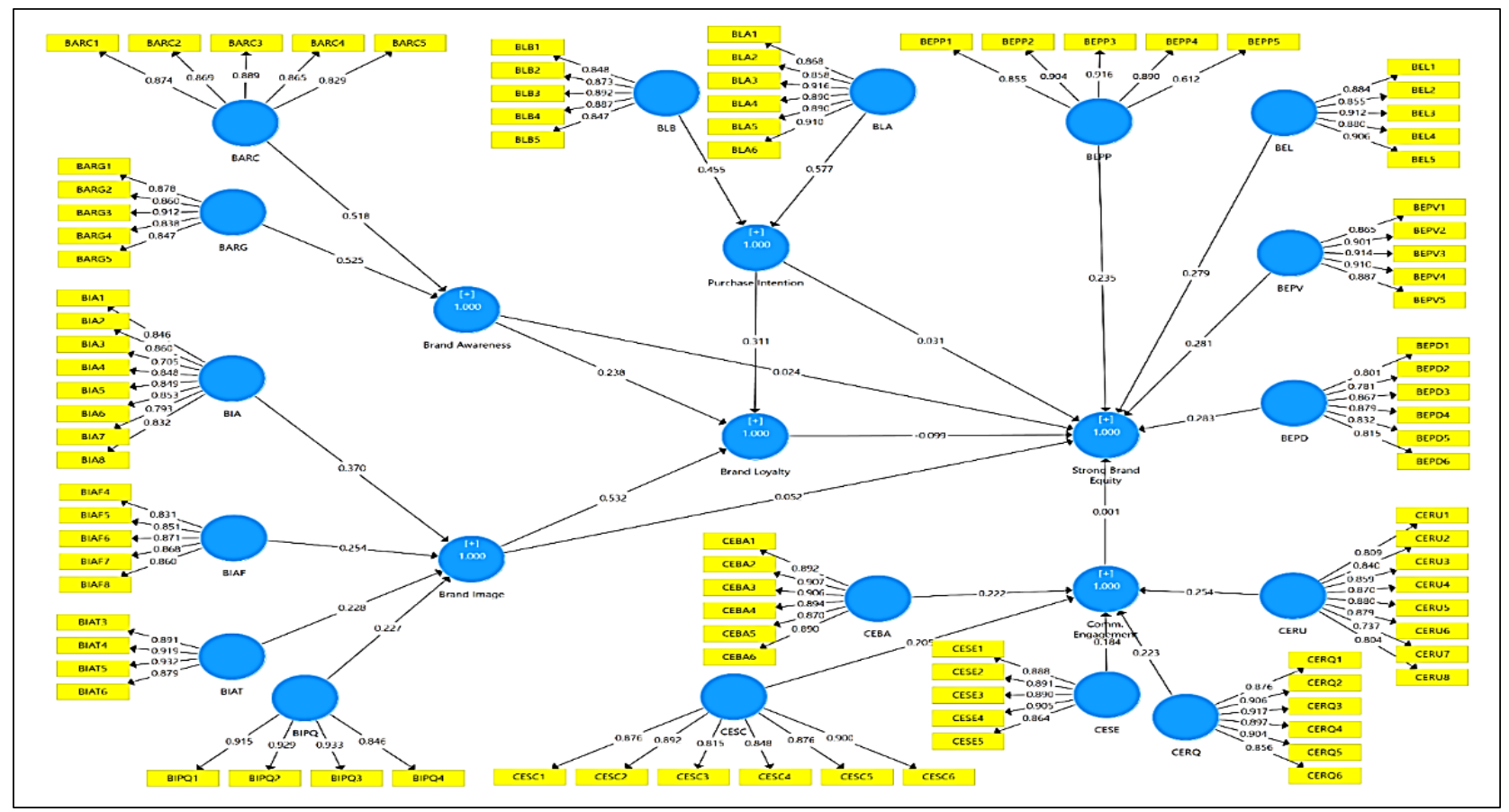

Figure 3. Evaluation of Reflective Measurement Model - A Reflective-Formative Type II HOC 'Mode A' in PLS Algorithm Regression Analysis

Furthermore, high internal consistency exceeds 0.90 in both CR and Cronbach's Alpha coefficient $(\alpha)$. Therefore, it suggested that the model fit exists in the reflective measurement model of LOC. On the other hand, Discriminant Validity validates latent variables to be distinctive from each other to avoid multicollinearity issues (Ab Hamid, Sami \& Sidek, 2017; Hair et. al., 2019). The study employed Fornell-Larcker criteria for cross-loadings assessment (Fornell \& Larcker,1981). The results showed that all indicators are loaded strongly on intended constructs compared to others in the model to denote high discriminant validity. However, the constructs of BIAF and BIA showed a slight difference $(0.839-0.825=0.014)$. According to Ab Hamid et. al., $(2017)$, the small dispute can be ignored. The path modeling of HOC in second-order and third-order constructs is treated as measurement model and structural model simultaneously, evaluated in Blindfolding Algorithm Analysis in SmartPLS version 3.2.8 (Ringle, Wende \& Becker, 2015) as Formative Measurement Model of Reflective-Formative Type II HOC 'Mode A' (Wong, 2013). The model fit was obtained by assessing collinearity issues in predictor variables through VIF values (Hair et. al., 2019) where the second-order constructs exhibit VIF values in the range between 3.362 and 6.236. Meanwhile, the third-order constructs exhibit the VIF values in the range between 2.102 and 5.087. Following the threshold, VIF values in the range between 1 and 10 indicate no collinearity issue in the HOC formative indicators. Figure 4 exhibits the model.

\section{Assessment of structural model}

In the Structural Model, the assessment on collinearity issues was conducted to avoid bias in the regression analysis where the results show that VIF values of predictor variables are in the range of $1 \geq x<10$ with no collinearity issue. The significance of path coefficients showed all path coefficient values are within the range of \pm 1 , thus, all paths are significant in the structural model. In addition, T statistics showed that all paths are statistically highly significant where $t$-value $>$ 3.30 based on a two-tailed test with $p$-value $\leq 0.001$. Figure 5 exhibits the model.

\section{Hypothesis testing using bootstrapping of direct effect results}

Statistical significance of each path coefficient for hypotheses testing was found in standardized beta $\beta$-value, $p$-value, and $\mathrm{T}$ statistics together with a confidence interval (CI) consisting of parameter estimates where CI level = $1-$ alpha level $(\alpha)$, where the significant level is at $2.5 \%$ when the CI level is $97.5 \%$. There are insignificances of the direct effect of IVs to DV with $p$-value $>0.05$. Thus, hypotheses $(\mathrm{H} 1),(\mathrm{H} 2)$, and $(\mathrm{H} 3)$ are not supported. In addition, BL also indicates an 
insignificant direct effect to predict SBE with $p$-value $>0.05$. Therefore, hypothesis (H7) is not supported. On the contrary, there are significant indirect effects of exogenous variables to predict BL with $p$-value $\leq 0.05$, thus, hypotheses (H4), (H5), and (H6) are supported.

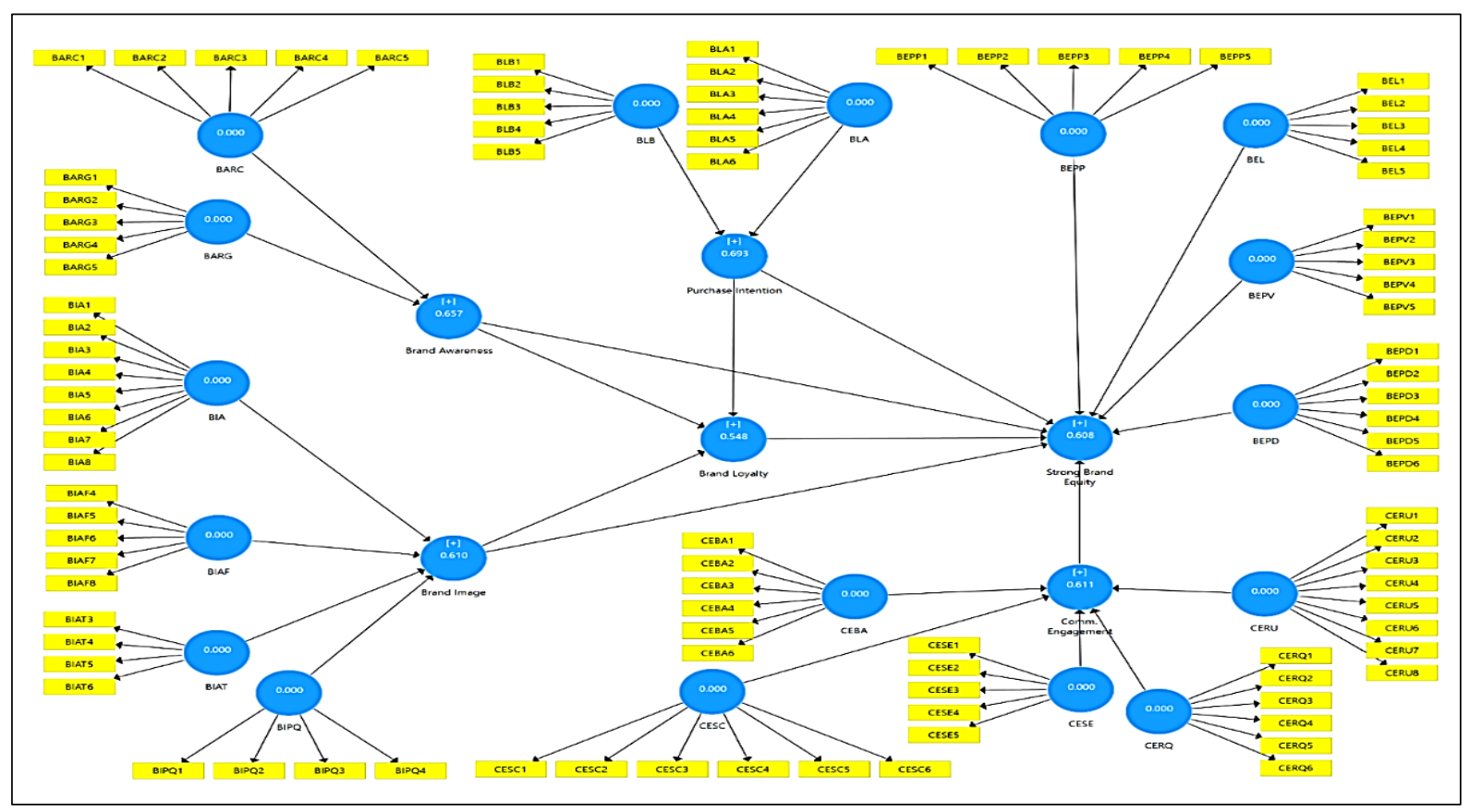

Figure 4. Evaluation of Formative Measurement Model - A Reflective-Formative Type II HOC 'Mode A' in Blindfolding Algorithm Analysis

\section{Mediating effects in the path analysis}

Table 1. Mediating effects of predictor and outcome variables involving brand loyalty

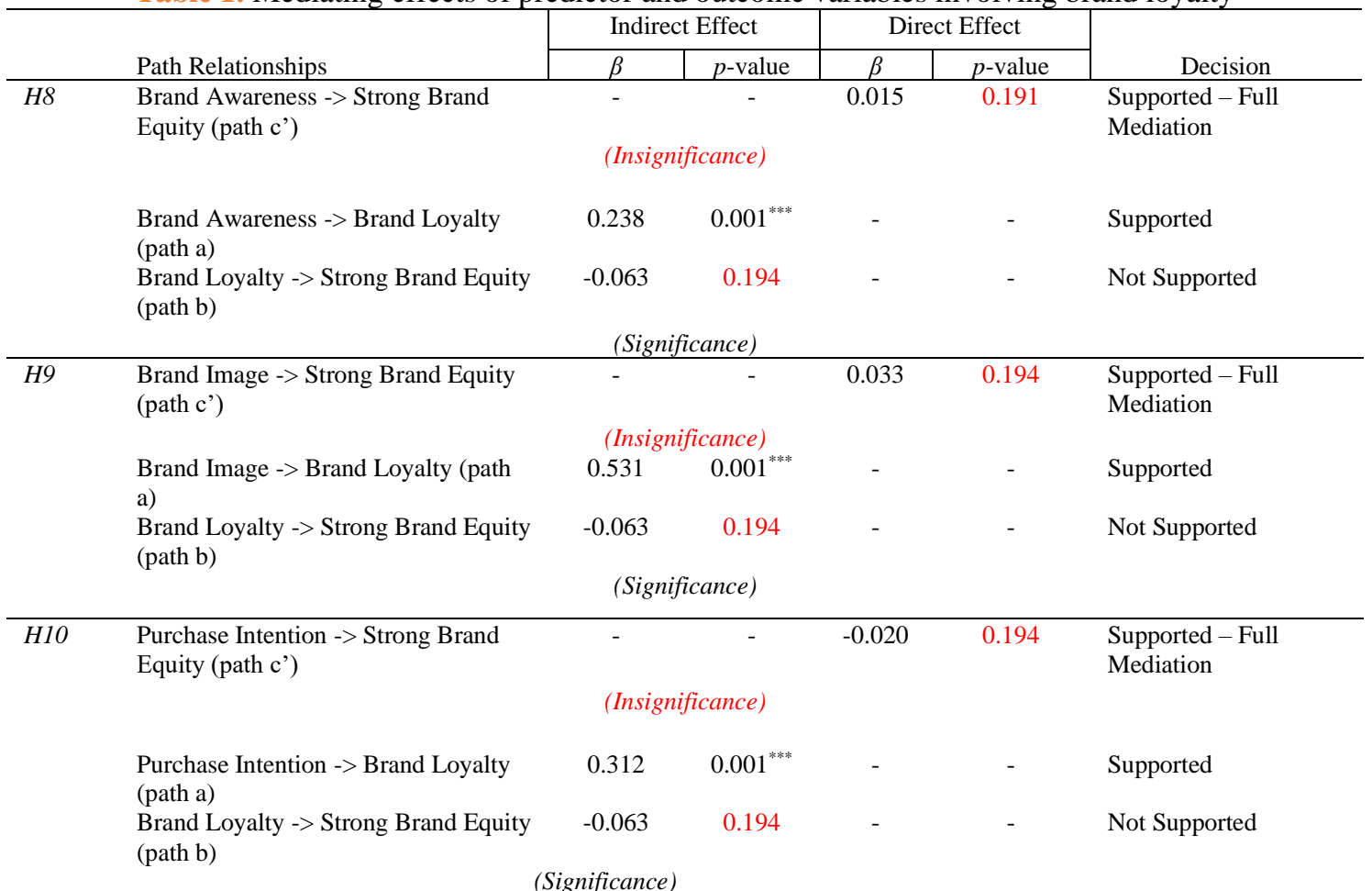




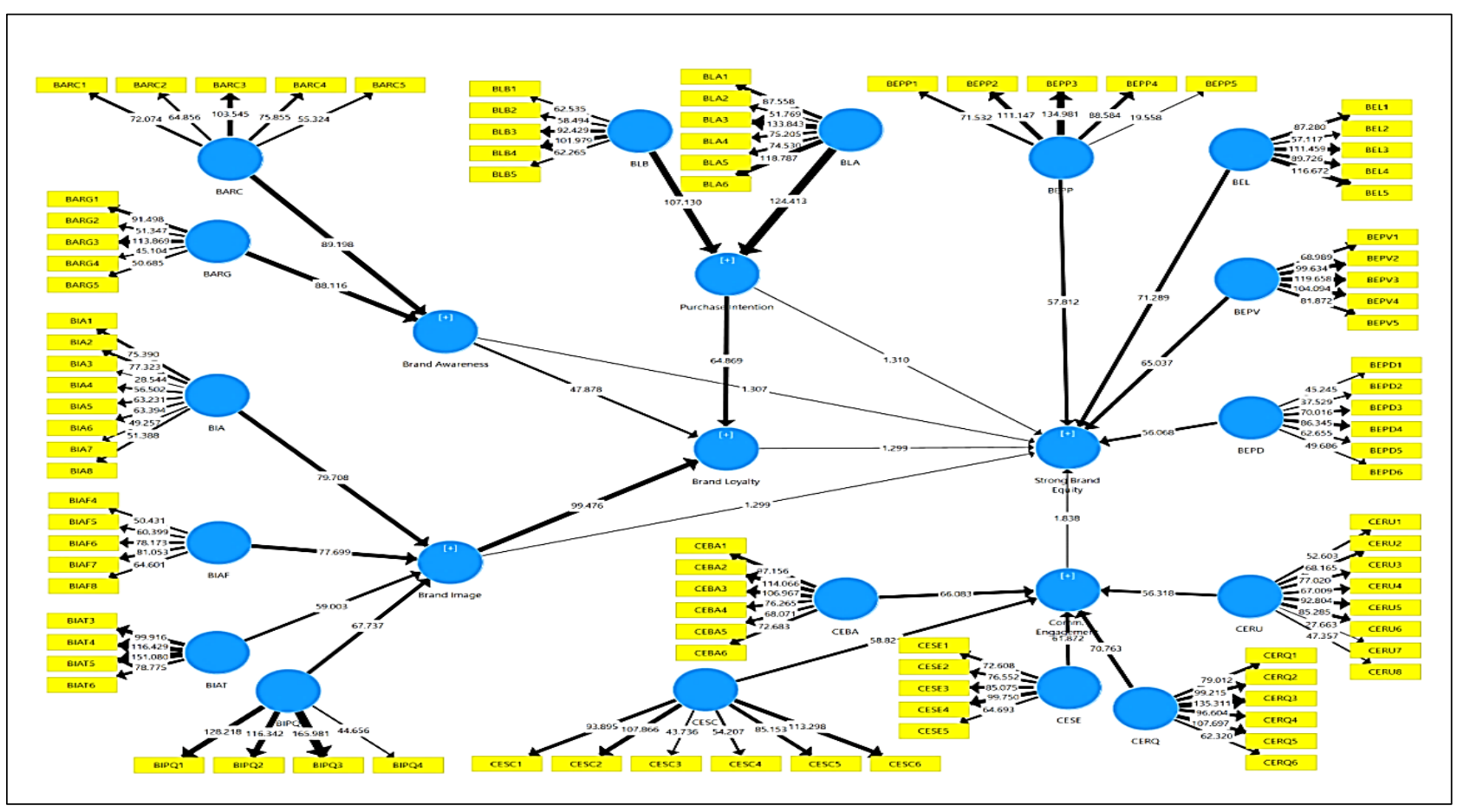

Figure 5. Evaluation of structural model in bootstrapping analysis

Following Baron and Kenny's approach (1986), the regression analysis involves IVs, mediator variables, and DV in Bootstrapping using SmartPLS version 3.2.8 (Ringle et. al., 2015). The results of the analysis are exhibited in Table 1, which exhibits the causal relationships that are fully mediated by BL as there are significant indirect effects whenever one or both of the pathways (a) or (b) found insignificant (Hayes, 2017). Therefore, the results showed evidence to support the hypotheses (H8), (H9), and (H10).

\section{Moderating effects in the path analysis}

The study employed Baron and Kenney (1986) suggestion on moderating effect by adding the multiplicative interactions which were analyzed using SmartPLS version 3.2.8 (Ringle et. al., 2015) in the multigroup analysis as the study has three (3) IVs of BA, BI, and PI in product-indicator approach (Chin, 1998). The results are shown in Table 2, indicating the moderating variable affects only on path relationship between BA and SBE where $(\beta$-value $=0.001, t$-value $=2.058)$ significant with $p$-value $\leq 0.05$ with a very low effect at $f^{2}=0.146$. Thus, hypothesis (H11) is supported. On the contrary, there are no moderating effect of CE on path relationships of BI $\rightarrow$ SBE and PI $->$ SBE with insignificant $p$ value $>0.05$ together with critically low effect size at $f^{2}=0.129$ and $f^{2}=0.077$ respectively. Therefore, the hypotheses (H17) and (H18) are rejected and not supported.

Table 2. Moderating effects of community engagement between IVs (predictor) and DV (outcome)

\begin{tabular}{|c|c|c|c|c|c|c|}
\hline & Relationship & $\beta$-value & $t$-value & $p$-value & $f^{2}$ & Decision \\
\hline \multirow[b]{2}{*}{ H11 } & $\begin{array}{l}\text { Comm. Engagement -> Strong Brand } \\
\text { Equity }\end{array}$ & 0.002 & 2.330 & $0.020^{*}$ & 0.165 & Supported \\
\hline & $\begin{array}{l}\text { Brand Awareness -> Strong Brand Equity } \\
\text { (Brand Awareness x Comm Engagement) - } \\
>\text { Strong Brand Equity }\end{array}$ & $\begin{array}{l}0.018 \\
0.001\end{array}$ & $\begin{array}{l}1.412 \\
2.058\end{array}$ & $\begin{array}{c}0.159 \\
0.040^{*} \\
\text { (Significance) }\end{array}$ & $\begin{array}{l}0.100 \\
0.146\end{array}$ & $\begin{array}{l}\text { Not Supported } \\
\text { Supported }\end{array}$ \\
\hline \multirow[b]{2}{*}{$H 12$} & $\begin{array}{l}\text { Comm. Engagement }->\text { Strong Brand } \\
\text { Equity }\end{array}$ & 0.002 & 2.294 & $0.022^{*}$ & 0.163 & Supported \\
\hline & $\begin{array}{l}\text { Brand Image -> Strong Brand Equity } \\
\text { (Brand Image x Comm Engagement) -> } \\
\text { Strong Brand Equity }\end{array}$ & $\begin{array}{l}0.039 \\
0.001\end{array}$ & $\begin{array}{l}1.308 \\
1.821\end{array}$ & $\begin{array}{l}0.192 \\
0.070\end{array}$ & $\begin{array}{l}0.093 \\
0.129\end{array}$ & $\begin{array}{l}\text { Not Supported } \\
\text { Not Supported }\end{array}$ \\
\hline \multirow[b]{2}{*}{$H 13$} & $\begin{array}{l}\text { Comm. Engagement }->\text { Strong Brand } \\
\text { Equity }\end{array}$ & 0.001 & 1.777 & 0.077 & 0.126 & Not Supported \\
\hline & $\begin{array}{l}\text { Purchase Intention } \rightarrow \text { Strong Brand Equity } \\
\text { (Purchase Intention x Comm Engagement) } \\
\rightarrow \text { Strong Brand Equity }\end{array}$ & $\begin{array}{l}0.023 \\
0.001\end{array}$ & $\begin{array}{l}1.305 \\
1.092\end{array}$ & $\begin{array}{l}0.193 \\
0.276\end{array}$ & $\begin{array}{l}0.093 \\
0.077\end{array}$ & $\begin{array}{l}\text { Not Supported } \\
\text { Not Supported }\end{array}$ \\
\hline
\end{tabular}




\section{CONCLUSION}

In conclusion, MOFBs has a low level of equity perceived which subsequently would affect business sustainability. Particularly, with the insignificance of direct effects found in the relationships between IVs and DV, it indicated that in the Malaysian context, the results showed opposite outcomes compared to previous studies(Aaker, 1991, 1996; Aaker \& Biel, 2013; Keller, 1993, 2001, 2003a, 2003b, 2016; Keller \& Brexendorf, 2016). Meanwhile, BL is concluded to have full mediating effects in the causal relationships. Therefore, MFOBs have to elevate CPM to the next level in achieving sustainable advantages in the loyalty dimension to give positive impacts on SBE building for business competitiveness in the marketplace.

In addition, $\mathrm{CE}$ is concluded of having low to no moderating effects on the causal relationships which are jeopardizing its innovative roles as a moderator in CPM for MOFBs' business sustainability. Even though past studies indicated that the significant roles of $\mathrm{CE}$ as an innovative moderator would turn commercial content moderation into financial success in the dimensions of satisfaction, trust, and commitment in eWOM, the results indicated otherwise in the Malaysian context, which is outrageous to MOFBs' business sustainability (Carvalho \& Fernandes, 2018; Seering et. al., 2019).

Therefore, MOFBs must interactively utilize technology advancement through the internet of things (IoT) platform in activating robust eWOM to build SBE for their business sustainability. IoT is the latest paradigm shift with the main goal is to connect the digital world to the ground of field application. In the era of IoT, many industries have aggressively started and utilized the internet and communication technology advancement in their daily operation to optimize sales and operation. Many international fashion brands have embraced IoT to give a better shopping experience for customers to develop co-creation values in service orientation through their interactions with IoT retail technology (Rese, Schlee \& Baier, 2019; Latif, Alghazo, Maheswar, Jayarajan \& Sampathkumar, 2020). A study by Balaji and Roy (2017) found that ease of use, superior functionality, aesthetic appeal, and presence are key determinants of value co-creation for IoT retail technology. The study also indicated that the co-creation values could influence customers to continuously hold purchase intention in repurchase and advocacy commitments, particularly in eWOM engagement in SNs community members. The findings gave further implications for MOFBs to progressively advance in their deliverables to enhance superior customer experience employed in $\mathrm{CE}$, in order to rejuvenate the innovative roles as a moderator variable in CPM which can strengthen the causal relationships for business sustainability.

\section{Limitations and directions for future study}

Limitations occur in the study were merely constraints in time, costs, and environmental factors. As CPM is conceptualized based on the environmental factors of the study, future studies should look into other models with different determinants of $\mathrm{CE}$ to innovatively strengthen the level of MOFBs equity in the marketplace. If time and costs are not the constraints, future study should also focus on different sampling procedures in different population samplings and regions of MFFI as well as other industries like Food and Beverages, Automobile, Healthcare, Fast-moving Consumer Goods, Telecommunication, and others. These opportunities would provide new referral frameworks to test CPM by industry, region, as well as by country aspects.

\section{REFERENCES}

Aaker, D. A. (1991). Managing Brand Equity. The Free Press, New York.

Aaker, D. A. (1996). Measuring Brand Equity Across Products and Markets. California management review, 38(3).

Aaker, D. A., \& Biel, A. . (2013). Brand equity \& advertising: advertising's role in building strong brands. Psychology Press.

Ab Hamid, M. R., Sami, W., \& Sidek, M. M. (2017). .(). . (2017). Discriminant validity assessment: Use of Fornell \& Larcker criterion versus HTMT criterion. Journal of Physics: Conference Series Vol. 890, No. 1, , p. 012163

Acar, A., \& Erkan, M. . (2018). How Much Does the Consumer-Based Brand Equity Affect the Financial Performance of the Company? . In Global Conference on Business and Economics (GLOBE 2018). Vol. 6.

Ahn, J. (2019). Cognitive antecedents and affective consequences of customers' self-concept in brand management: A conceptual model. International Journal of Contemporary Hospitality Management. Vol. 31(5), pp. 2114-2128.

Aini, Q., Zuliana, S. R., \& Santoso, N. P. L. (2018). Management Measurement Scale as A Reference to Determine Interval in A Variable. Aptisi Transactions on Management, Vol. 2(1), pp. 45-55.

Aminu, S. G., \& Ahmad, N. (2018). An Evaluation of the Effects of Brand Equity on Consumer Willingness to Pay Price Premium. International Journal of Marketing Research Innovation, 2(1), 64-72.

Balaji, M. S., \& Roy, S. K. (2017). Value co-creation with Internet of things technology in the retail industry. Journal of Marketing Management, 33(1-2), 7-31.

Baron, R. M., \& Kenny, D. A. (1986). The moderator-mediator variable distinction in social psychological research: Conceptual, strategic, and statistical considerations. Journal of personality and social psychology, Vol. 51(6), p. 1173.

Bettman, J. R. (1970). Information processing models of consumer behavior. Journal of Marketing Research, 7(3), 370-376.

Bettman, J. R. (1979). Information processing theory of consumer choice. Addison-Wesley Pub. Co.

Braun, R. (2018). Consumers' Willingness to Pay for Specialty Table Eggs. Supply Chain Management Undergraduate Honors Theses Retrieved from https://scholarworks.uark.edu/scmtuht/9

Camilleri, M. A., \& Rather, R. (2019). The effects of service quality and consumer-brand value congruity on hospitality brand loyalty.

Candrlic, S., Katić, M. A., \& Dlab, M. H. (2014). Online vs. paper-based testing: A comparison of test results. In 2014 37th International Convention on Information and Communication Technology, Electronics and Microelectronics (MIPRO) (pp. 657662). IEEE. 
Carvalho, A., \& Fernandes, T. (2018). Understanding customer brand engagement with virtual social communities: A comprehensive model of drivers, outcomes and moderators. Journal of Marketing Theory and Practice, 26(1-2), 23-37.

Chan, H. Y., Boksem, M., \& Smidts, A. (2018). Neural profiling of brands: Mapping brand image in consumers' brains with visual templates. Journal of Marketing Research, 55(4), 600-615.

Chattopadhyay, T., Shivani, S., \& Krishnan, M. (2010). Marketing mix elements influencing brand equity and brand choice. Vikalpa, 35(3), 67-84.

Chen, I. J., \& Paulraj, A. (2004). 'Towards a theory of supply chain management: the constructs and measurements.' Journal of operations management, 22(2), 119-150.

Chin, W. W. (1998). The partial least squares approach to structural equation modeling. G. A. Marcoulides (Ed.), Modern methods for business research, pp. 295-358.

Cohen, J. (1988). Statistical power analysis for the behavioural sciences (2nd ed.). Hillsdale, NJ: Erlbaum.

Corner, P. D. (2002). An integrative model for teaching quantitative research design. Journal of Management Education, Vol. 26(6), pp. 671-692.

Dillman, D. A. (2000). Mail and Internet surveys: The tailored design method. New York: Wiley \& Sons.

Faul, F., Erdfelder, E., Lang, A.-G. \& Buchner, A. . (2007). G*Power 3: A flexible statistical power analysis program for the social, behavioural, and biomedical sciences. Behaviour Research Methods, Vol. 39, pp. 175-191

Fischer, K. W. (1980). A theory of cognitive development: The control and construction of hierarchies of skills. Psychological review, , 87(6), 477.

Foroudi, P., Jin, Z., Gupta, S., Foroudi, M. M., \& Kitchen, P. J. . (2018). Perceptional components of brand equity: Configuring the Symmetrical and Asymmetrical Paths to brand loyalty and brand purchase intention. Journal of Business Research, Vol. 89, pp. 462-474.

Foroudi, P. (2019). Influence of brand signature, brand awareness, brand attitude, brand reputation on hotel industry's brand performance. International journal of hospitality management, Vol. 76, pp. 271-285.

Fornell, C., \& Larcker, D. F. (1981). Evaluating Structural Equation Models with Unobservable Variables and Measurement Error. Journal of Marketing Research, Vol. 18(1), pp. 39-50.

Gómez, M., Martín-Consuegra, D., Díaz, E., \& Molina, A. (2018). Determinants and outcomes of price premium and loyalty: A food case study. Journal of Consumer Behaviour, 17(1), 64-74.

Hair, J. F., Risher, J. J., Sarstedt, M., \& Ringle, C. M. . (2019). When to Use and How to Report the Results of PLS-SEM. European Business Review, Vol. 31(1), pp.2-24.

Hayes, A. F. (2017). Introduction to mediation, moderation, and conditional process analysis: A regression-based approach. Guilford publications.

Hertzog, M. A. (2008). Considerations in determining sample size for pilot studies. Research in nursing \& health, Vol. 31(2), pp. 180191.

Howard, M. C. (2018). Scale Pretesting. Practical Assessment. Research \& Evaluation, Vol. 23(5).

Islam, J. U., \& Rahman, Z. (2016). Examining the effects of brand love and brand image on customer engagement: An empirical study of fashion apparel brands. Journal of Global Fashion Marketing, 7(1), 45-59.

Joshi, A., Kale, S., Chandel, S., \& Pal, D. K. (2015). Likert scale: Explored and explained. British Journal of Applied Science \& Technology, Vol. 7(4), p.396.

Keller, K. L. (1993). Conceptualizing, Measuring, and Managing Customer-Based Brand Equity. Journal of Marketing, Vol. 57 , No. 1 pp. 1-22.

Keller, K. L. (2001). Customer-Based brand Equity Model. Cambridge, MA: Marketing Science Institute., pp. 3-27.

Keller, K. L. (2003a). Brand synthesis The multidimensionality of brand knowledge. Journal of Consumer Research, Vol 29(4), pp. 595-600.

Keller, K. L. (2003b). Understanding brands, branding and brand equity. Interactive Marketing, Vol. 5(1), pp. 7-20.

Keller, K. L. (2016). Reflections on customer-based brand equity: perspectives, progress, and priorities. AMS Review, Vol. 6(1-2), pp. $1-16$.

Keller K.L., Brexendorf T.O. (2016) Strategic Brand Management Process. In: Esch FR. (eds) Handbuch Markenführung. Springer Reference Wirtschaft. Springer Gabler, Wiesbaden. https://doi.org/10.1007/978-3-658-13361-0_8-1

Khan, N., Rahmani, S. H. R., Hoe, H. Y., \& Chen, T. B. (2015). Causal relationships among dimensions of consumer-based brand equity and purchase intention: Fashion industry. International Journal of Business and Management, 10(1), 172.

Latif, G., Alghazo, J. M., Maheswar, R., Jayarajan, P., \& Sampathkumar, A. (2020). Internet of Things: Reformation of Garment Stores and Retail Shop Business Process. In Integration of WSN and IoT for Smart Cities (pp. 115-128). Springer, Cham.

Mohamed, R. N., Mohamad, B., Borhan, H., Osman, I., \& Kamaralzaman, S. (2019). The-Determinant-Factors-of-Supply-ChainManagement-on-Purchase-Intention-of-an-International-Branded-Apparels-Status-Quo. International Supuly Chain. Mgt, Vol, $8(3), 677$.

Mutepfa, M. M., \& Tapera, R. (2019). Traditional Survey and Questionnaire Platforms. Handbook of Research Methods in Health Social Sciences, pp. 541-558.

Nardi, P. M. (2018). Doing survey research: A guide to quantitative methods. Routledge.

Nguyen, T. N. D., \& Nguyen, B. T. (2019). The relationship between online trust, customer engagement and eWOM. Journal of Science Hcmc Ou-Economics and Business Administration, 9(1).

Nguyen, B., Wu, M. S. S., \& Chen, C. H. S. (2017). How does self-concept and brand personality affect luxury consumers' purchasing decisions? In Luxury Fashion Retail Management (pp. 19-48). Springer, Singapore.

Nielsen. (2017). Global Brands are winning the Battle for Malaysian Consumers' Hearts and Minds. Retrieved from https://www.nielsen.com/my/en/insights/news/2017/global-brands-are-winning-consumers-hearts-and-mind.html. Dated 7 Dec, 2018

Perneger, T. V., Courvoisier, D. S., Hudelson, P. M., \& Gayet-Ageron, A. (2015). Sample size for pre-tests of questionnaires. Quality of Life Research, Vol. 24(1), pp. 147-151.

Ramayah, T., Cheah, J., Chuah, F., Ting, H., \& Memon, M. A. . (2018). Partial Least Squares Structural Equation Modeling Using SmartPLS 3.0. 
Rather, R. A., \& Sharma, J. (2017). The effects of customer satisfaction and commitment on customer loyalty: Evidence from the hotel industry. JOHAR, 12(2), 41.

Rese, A., Schlee, T., \& Baier, D. (2019). The need for services and technologies in physical fast fashion stores: Generation Y's opinion. Journal of Marketing Management, 35(15-16), 1437-1459.

Ringle, C. M., Wende, S., \& Becker, J. M. . (2015). SmartPLS 3.’ Boenningstedt: SmartPLS GmbH. http://www. smartpls. com.

Seering, J., Wang, T., Yoon, J., \& Kaufman, G. (2019). Moderator engagement and community development in the age of algorithms. New Media \& Society, 21(7), 1417-1443.

Speak, A., Escobedo, F. J., Russo, A., \& Zerbe, S. (2018). 'Comparing convenience and probability sampling for urban ecology applications.' Journal of applied ecology, 55(5), 2332-2342.

Srivastava, M., \& Sivaramakrishnan, S. (2020). Exploring The Triad of eWOM, eWOM Generator Engagement and Consumer Engagement: A Conceptual Framework. Journal of Management Research, 20(1), 34-46.

Statistica. (2020). Malaysia Fashion. Retrieved from https://www.statista.com/outlook/244/122/fashion/malaysia. Dated 10, February, 2020.

Su, J., \& Chang, A. (2018). Factors affecting college students' brand loyalty toward fast fashion. International Journal of Retail \& Distribution Management, 46(1), 90-107. doi:10.1108/ijrdm-01-2016-0015

Taber, K. S. (2018). The use of Cronbach's alpha when developing and reporting research instruments in science education. Research in Science Education, Vol. 48(6) pp. 1273-1296.

Tajuddin, R. M. Hashim, S.F. and Zainol, A.S. (2018). Impacts of Consumer-Brand Identification for Strengthening the Sustainability of Malaysian Fashion Brands. International Journal of Supply Chain Management, Vol. 7, No. 4, pp.,254- 264.

Tehseen, S., Sajilan, S., Gadar, K., \& Ramayah, T. . (2017). 'Assessing Cultural Orientation as a Reflective-Formative Second Order Construct-A Recent PLS-SEM Approach. Review of Integrative Business and Economics Research, Vol. 6(2), p. 38.

TheEdge. (2018). Can Padini maintain its style despite tough conditions. Retrieved from:https://www.theedgemarkets.com/article/canpadini-maintain-its-style-despite-tough-conditions.

Valaei, N., \& Nikhashemi, S. R. (2017). Generation Y consumers' buying behaviour in fashion apparel industry: a moderation analysis. Journal of Fashion Marketing and Management: An International Journal, 21(4), 523-543. doi:10.1108/jfmm-01-2017-0002.

Wagner III, W. E. (2019). Using IBM® SPSS® statistics for research methods and social science statistics. Sage Publications.

Wong, K. K. K. (2013). 'Partial Least Squares Structural Equation Modeling (PLS-SEM) Techniques Using SmartPLS.' Marketing Bulletin, 24(1), 1-32.

Yeap, J. A. L., Thurasamy, R., \& Yapp, E. H. T. (2018). Key Drivers of Brand Loyalty among Malaysian Shoppers: Evidence From a Japanese Fashion Retailer. Asian Academy of Management Journal, 23(2), 1-24. doi:10.21315/aamj2018.23.2.1

Zhang, J., Shabbir, R., Pitsaphol, C., \& Hassan, W. (2015). Creating brand equity by leveraging value creation and consumer commitment in online brand communities: A conceptual framework. International Journal of Business and Management, 10(1), 80 .

Zhu, X., Teng, L., Foti, L., \& Yuan, Y. (2019). Using self-congruence theory to explain the interaction effects of brand type and celebrity type on consumer attitude formation. Journal of Business Research.

\section{ACKNOWLEDGEMENT}

The authors would like to thank the Faculty of Art \& Design, University of Technology MARA, Shah Alam, Malaysia for supporting the research which is a requirement for $\mathrm{PhD}$ completion. The study was done not only for extending the body of knowledge but also to be practised in the field of study for the benefits of Malaysian Fashion Brands in Fast-fashion industry. Special thanks to anonymous respondents who had participated in the research survey to obtain the rightful perception towards the local brands. 


\section{AUTHORS' BIOGRAPHY \& AUTHOR PROFESSIONAL PICTURE}

\section{Siti Fatimah Hashim*}



Her years of experience in industry has led her to academic world. She was a Senior Lecturer in Post-Graduate Center, LUCT. Curently, she teaches in UiTM. Her PhD focuses on Strategic Brand Management in Fastfashion industry. She won a Research Grant GIP-UiTM(2017), Excellent Papers ABRIC2016 and several commendations from international journals.

\section{Assoc. Prof. Dr. Rosita Mohd. Tajuddin}

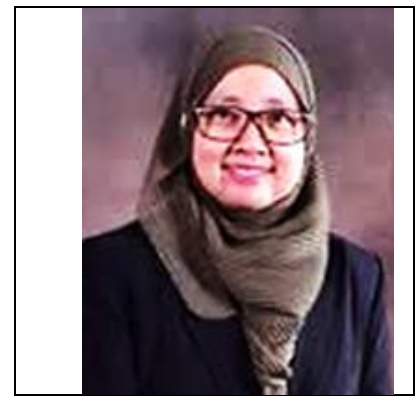

She has 20 years of teaching experience. Graduated from Iowa State University, Ames, IA. USA with PhD in 2011 majoring in Apparel, Merchandising \& Design Specialization. She had several research grants with the latest is FRGS Grant2019. Currently, she is the Head of Postgraduate Studies, Faculty of Art \& Design, UiTM.

\section{Prof. Dr. Amer Shakir Zainol}

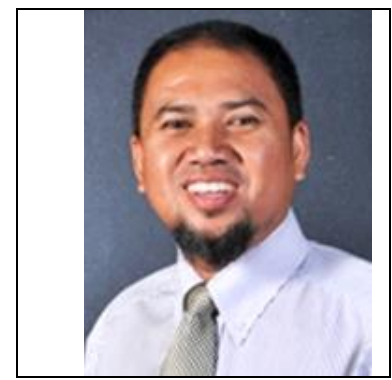

He is a director of IMPAK, UiTM with exceeding 20 years of teaching experience with Phd in Art And Design. An expert in Psychology of Creativity Art and Personality Traits. Received Excellent Sevice Award 2004, 2011; Best Paper Award in SSSR2011 Asean Conference, Academic Excellence Award for Ph.D (2010) and others. 